\title{
SINTESIS KARBOKSIMETIL SELULOSA (CMC) DARI SELULOSA KULIT DURIAN (Durio zibethinus)
}

\section{[Synthesis of Carboxymethyl Cellulose (CMS) of Durian Peel (Durio Zibethinus) Cellulose]}

\author{
Dini Safitri $^{1^{*}}$, Erwin Abdul Rahim ${ }^{1}$, Prismawiryanti $^{1}$, Rismawati Sikanna ${ }^{1}$ \\ 1) Jurusan Kimia, Fakultas Matematika dan IImu Pengetahuan Alam, Universitas Tadulako. \\ Jl. Soekarno Hatta, Kampus Bumi Tadulako Tondo Palu, Telp. 0451- 422611
}

Diterima 30 Desember 2016, Disetujui 1 Maret 2017

\begin{abstract}
The investigation about of carboxymethyl cellulose (CMC) of Durian peel (Durio zibethinus) cellulose has been done. The research aim is to determine the best ratio of sodium mono-chloroacetate toward cellulose and is to determine the reaction time in the synthesis of carboxymethyl cellulose of durian peel in order to obtain the highest substitution degree. The applied of ratio variations and reaction time were 5:5, 6:5, 7:5, 8:5, 9:5 grams and 1, 2, 3, 4, 5, respectively. The result showed that the best ratio of sodium mono-chloroacetate toward cellulose was 7:5 gram with yields and the substitution degree of $39.39 \%$ and 1.17 , respectively. The best time reaction was found at 4 hours with yields and the substitution degree of $39.77 \%$ and 1.2 , respectively.
\end{abstract}

Keywords: Durian peel, carboxymethyl cellulose, substitution degree.

\begin{abstract}
ABSTRAK
Telah dilakukan penelitian tentang sintesis karboksimetil selulosa (CMC) dari selulosa kulit durian (Durio zibethinus). Penelitian ini bertujuan untuk menentukan rasio natrium monokloroasetat / selulosa dan waktu reaksi dalam sintesis karboksimetil selulosa dari kulit durian (Durio zibethinus) untuk memperoleh derajat subsitusi tertinggi. Variasi rasio yang digunakan adalah 5:5, 6:5, 7:5, 8:5, dan 9:5 gram serta waktu reaksi yang digunakan adalah 1,2, 3, 4, dan 5 jam yang masing-masing dilakukan secara duplo. Dari hasil penelitian diperoleh rasio natrium monokloroasetat / selulosa terbaik yaitu 7:5 gram dengan rendemen sebesar 39,93 \% dan nilai derajat subsitusi sebesar 1,17. Sedangkan hasil karboksimetil selulosa diperoleh waktu reaksi terbaik adalah 4 jam dengan rendemen sebesar 39,77\% dan nilai derajat sibsitusi sebesar 1,2.
\end{abstract}

Kata kunci : kulit durian, karboksimetil selulosa, derajat subsitusi. 


\section{LATAR BELAKANG}

Limbah tumbuhan yang terbuang merupakan salah satu sumber pencemar lingkungan akibatnya akan menibulkan penyakit, dilain pihak tentunya mengurangi keindahan kota dan masih banyak masalah yang lain. Salah satunya adalah limbah kulit durian, yaitu limbah organik yang tidak dimanfaatkan. Mengacu pada struktur kulit durian yang keras dan berserat, maka sangat potensial untuk diolah menjadi suatu produk. Salah satu potensi kulit durian yaitu sebagai bahan baku pembuatan Carboxymethyl cellulose (CMC). Kulit durian memiliki kandungan selulosa yang tinggi (50-60\%), lignin (5\%) dan pati (5\%) (Kurniawan dkk, 2013).

Berdasarkan kandungannya tersebut, maka kulit durian potensial untuk diolah menjadi senyawa CMC.

CMC adalah salah satu senyawa hasil modifikasi selulosa dan banyak dimanfaatkan pada industri farmasi, makanan, tekstil, detergen, dan produk kosmetik. CMC biasanya digunakan untuk pengental, penstabil emulsi, dan bahan pengikat (Wijayani dkk., 2005). Awalnya CMC diproduksi dari selulosa kayu karena memiliki kandungan selulosa $42-47 \%$ (Dumanauw, 1990).

Pembuatn CMC dipengaruhi oleh proses alkalisasi dan karboksimetilasi yang selanjutnya menentukan mutu CMC yang dihasilkan. Proses alkalisasi menggunakan basa $\mathrm{NaOH}$. Alkalisasi adalah untuk mengaktifkan gugus- gugus hidroksil $(-\mathrm{OH})$ dari selulosa untuk selanjutnya dilakukan reaksi karbosimetilasi. Selain itu, tujuan penambahan $\mathrm{NaOH}$ adalah sebagai pengembang selulosa, yang bertujuan memudahkan difusi reagen karboksimetilasi. Tahap karboksimetilasi menggunakan asam monokloroasetat ataupun bentuk garamnya. Jumlah penggunaan natrium monokloroasetat merupakan faktor lain mempengaruhi proses substitusi pada molekul selulosa (Pribadi, 1985). Seiring dengan bertambahnya jumlah basa yang digunakan akan mempermudah dan mempercepat proses difusi monokloroasetat menuju ke gugus hidroksil pada selulosa (Wijayani dkk, 2005).

$\begin{array}{ccc}\text { Dilihat dari fungsi } & \text { natrium } \\ \text { hidroksida } & \text { dan } & \text { natrium }\end{array}$
monokloroasetat maka komposisi kedua reagen baik reagen alkalisasi maupun karboksimetlilasi dalam proses ini sangat menentukan kualitas CMC yang akan dihasilkan. Bidin (2010) melaporkan bahwa pembuatan CMC dari jerami padi menghasilkan nilai derajat subsitusi terbaik $(1,48)$ pada penggunaan rasio natrium monokloroasetat terhadap selulosa 6:5 yang direaksikan selama 4 jam. Hasil tersebut lebih baik bila dibandingkan dengan penelitian sebelumnya yang 
dilakukan oleh Wijayani dkk (2005) yang menggunakan selulosa eceng gondok sebagai bahan dasar pembuatan CMC dengan nilai derajat subsitusi sebasar 0,85.

Penelitian ini dilakukan untuk menghasilkan CMC dengan karakteristik sesuai dengan standar yang berlaku. Proses penambahan jumlah reagen alkalisasi dan reagen karboksimetilasi diharapkan dapat meningkatkan derajat subtitusi. Maka melalui penelitian ini diharapkan diperoleh CMC dengan kualitas yang lebih baik sehingga dapat berkontribusi bagi kemajuan penegetahuan dalam hal pemanfaatan limbah menjadi produk bernilai ekonomi tinggi.

\section{METODE PENELITIAN}

\section{Bahan dan Peralatan}

Bahan yang digunakan dalam penelitian ini adalah serbuk kulit durian (Durian Montong), natrium hidroksida, metanol, natrium monokloroasetat, hidrogen peroksida, asam asetat glasial, asam nitrat, asam klorida, etanol, akuades dan indikator PP.

Peralatan yang digunakan dalam penelitian adalah Seperangkat alat Spektrofotometer Fourier Transform Infra Red (FTIR) Prestige 21 Shimadzu, penangas air, oven analitik Memmert, termometer, ayakan ukuran 60 mesh, neraca analitik, desikator, hot plate Cimarec, buret statif dan klem, kain saring, kertas $\mathrm{pH}$, viskometer ostwald, gilingan tepung, mortar agate, $\mathrm{KBr}$ Die, Pressure, plat $\mathrm{KBr}$ dan alat-alat gelas yang umum digunakan dalam laboratorium kimia.

\section{Prosedur Penelitian}

Delignifikasi Kulit Durian (Nur'ain, 2016)

Serbuk kulit durian direndam dengan menggunakan larutan natrium hidroksida $10 \%$ dengan perbandingan pelarut $1: 10$ $(b / v)$, kemudian diaduk dengan rata sampai seluruh serbuk kulit durian terendam sempurna. Perendaman dilakukan selama 24 jam. Setelah itu disaring dengan menggunakan kain saring. Residu yang diperoleh kemudian direndam kembali dengan menggunakan larutan hidrogen peroksida $10 \%$ perendaman ini dilakukan selama 24 jam. Kemudian campuran tersebut disaring dan residu yang dihasilkan dicuci dengan aquadest yang telah dididihkan hingga bau hidrogen peroksida hilang. Residu kemudian dimasukkan ke dalam cawan petri, lalu dikeringkan di dalam oven dengan suhu $60^{\circ} \mathrm{C}$ hingga berat konstan. Rendemen selulosa ditentukan dengan rumus sebagai berikut :

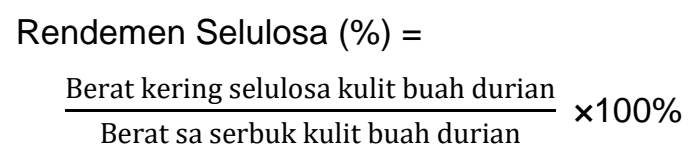

Variasi Natrium Monokloroasetat untuk Sintesis Karboksimetil Seluosa (Nur'ain, 2016)

5 gram berat kering selulosa kulit durian dimasukkan kedalam erlenmeyer $250 \mathrm{ml}$ ditambahkan $100 \mathrm{~mL}$ aquadest. Selanjutnya ditambahkan $10 \mathrm{ml}$ larutan $\mathrm{NaOH} 30 \%$ tetes demi tetes selama 1 
jam. Setelah selesai dilanjutkan proses karboksimetilasi dengan menambahkan $\mathrm{ClCH}_{2} \mathrm{COONa}$ sebanyak (5 g). Campuran kemudian dipanaskan dengan suhu $60^{\circ} \mathrm{C}$ selama 3 jam. Setelah itu campuran disaring dan residunya direndam menggunakan $100 \mathrm{ml}$ metanol selama 24 jam. Kemudian campuran dinetralkan menggunakan larutan asam asetat glasial. Campuran kemudian disaring kembali dan residunya dikeringkan di dalam oven dengan suhu $60^{\circ} \mathrm{C}$ hingga beratnya konstan. Karboksimetil selulosa yang dihasilkan ditentukan, rendemen dan derajat subtitusinya. Perlakuan untuk variasi $\mathrm{ClCH}_{2} \mathrm{COONa}(6 \mathrm{~g}, 7 \mathrm{~g}, 8 \mathrm{~g}$ dan 9 g) mengikuti prosedur diatas.

\section{Variasi waktu reaksi sintesis karboksimetil selulosa (Nur'ain, 2016)}

5 gram berat kering selulosa kulit durian dimasukkan kedalam erlenmeyer $250 \mathrm{ml}$ ditambahkan $100 \mathrm{~mL}$ aquadest. Selanjutnya ditambahkan $10 \mathrm{ml}$ larutan $\mathrm{NaOH} 30 \%$ tetes demi tetes selama 1 jam. Untuk mengetahui kondidsi optimum waktu reaksi sintesis karboksimetil selulosa, digunakan natrium monokloroasetat yang menghasilkan derajat subtitusi tertinggi dengan waku reaksi yaitu 1 jam, 2 jam, 3 jam, 4 jam dan 5 jam yang dipanaskan pada suhu $60^{\circ} \mathrm{C}$. Campuran kemudian disaring dan residunya direndam menggunakan $100 \mathrm{ml}$ metanol selama 24 jam. Kemudian campuran dinetralkan menggunakan larutan asam asetat glasial. Campuran kemudian disaring kembali dan residunya dikeringkan di dalam oven dengan suhu $60^{\circ} \mathrm{C}$ hingga beratnya konstan. Setelah itu, karboksimetil selulosa yang dihasilkan ditentukan derajat substitusinya.

\section{Penentuan Derajat Subtitusi (Nur'ain, 2016)}

Dua gram karboksimetil selulosa dicampurkan dengan $60 \mathrm{ml}$ larutan etanol 95\% sambil diaduk secara merata. Kemudian ke dalamnya ditambahkan 10 $\mathrm{ml}$ larutan asam nitrat $2 \mathrm{M}$ dan campuran diaduk kembali selama 2 menit. Campuran dipanaskan selama 5 menit dan kembali diaduk selama 15 menit. Setelah itu, campuran disaring dan residunya dicuci menggunakan $30 \mathrm{ml}$ larutan etanol 95\% yang telah dipanaskan sampai $60^{\circ} \mathrm{C}$. Residu selanjutnya dicuci kembali menggunakan larutan metanol, dan dilanjutkan pengeringan di dalam oven pada suhu $105^{\circ} \mathrm{C}$ sampai 3 jam. 0,5 g residu dimasukkan di dalam erlenmeyer lalu ditambahkan $100 \mathrm{ml}$ aquadest sambil di aduk. Setelah itu, menambahkan $25 \mathrm{ml}$ larutan natrium hidroksida $0,5 \mathrm{~N}$, lalu dipanaskan selama 15 menit. Dalam keadaan panas, campuran tersebut dititrasi dengan larutan asam klorida 0,3 N dan menggunakan indikator pp.

Derajat subsitusi ditentukan dengan persamaan berikut :

$$
\begin{aligned}
\% \text { CMC } & \text { (Persen Karboksimetil) } \\
= & {[(\text { Vo- Vn }) \times 0,058 \times 100] / \mathrm{M} }
\end{aligned}
$$

Derajat Subsitusi (DS)

$$
=[162 \times \% \text { CMC } /[5800-(57 \times \% C M C)]
$$


Keterangan :

$\mathrm{Vo}=\mathrm{ml}$ asam klorida yang digunakan untuk menitrasi blanko,

$\mathrm{Vn}=\mathrm{ml}$ asam klorida yang digunakan untuk menitrasi sampel, dan

$M=$ berat sampel (gram).

Pengukuran Berat molekul (Habibah, 2013)

Ditimbang 0,025 gram karboksimetil selulosa. Dimasukkan ke dalam labu ukur $25 \mathrm{~mL}$ dan dilarutkan sedikit demi sedikit dengan aquadest hingga garis batas labu takar. Setelah larut dihomogenkan campuran. Dimasukkan larutan ke dalam viskometer Ostwald. Dicatat waktu alir dari campuran tersebut. Dilakukan sebanyak tiga kali. Dilakukan prosedur yang sama untuk setiap karboksimetil selulosa dengan variasi konsentrasi larutan $(0,0375 \mathrm{~g} / 25$ $\mathrm{mL} ; 0,05 \mathrm{~g} / 25 \mathrm{~mL} ; 0,0625 \mathrm{~g} / 25 \mathrm{~mL} ; 0,075$ $\mathrm{g} / 25 \mathrm{~mL} ; 0,0875 \mathrm{~g} / 25 \mathrm{~mL} ;$ dan $0,1 \mathrm{~g} / 25$ $\mathrm{mL})$.

Viskositas spesifik $\eta s p=\frac{t-t_{0}}{t_{0}}$

Viskositas intrinsik $\quad[n]=(n s p / c)$

$$
\eta=\mathrm{KM}^{\alpha}
$$

Keterangan :

$\mathrm{K}$ dan $\mathrm{a}=$ Konstanta Mark-Houwink $(\mathrm{K}=1,7 \times 10$

${ }^{2}$ dan $\mathrm{a}=0,91$ )

$\eta=$ Viskositas intrinsik

$\mathrm{t}=$ waktu alir zat

$\mathrm{t}_{0}=$ waktu alir pelarut

$\mathrm{M}=$ Bobot molekul zat

$\mathrm{C}=$ Konsentrasi

\section{Pengukuran pH (Wijayani dkk, 2005)}

Ditimbang $1 \mathrm{~g}$ berat kering $\mathrm{CMC}$, ditambahkan $100 \mathrm{~mL}$ aquadest kemudian dipanaskan sampai suhu $70{ }^{\circ} \mathrm{C}$ sambil diaduk sampai larut dan setelah dingin diukur pH-nya.

\section{Analisis Spektrum FTIR}

Disiapkan zat $\mathrm{KBr}$ p.a yang sudah dioven 24 jam ( $\mathrm{KBr}$ kering bebas air) kemudian diambil sampel sebanyak $15 \mathrm{mg}$ diletakkan diatas mortar yang telah dibersihkan dengan aseton p.a dan tissue. Selanjutnya Diambil sejumlah zat $\mathrm{KBr}$ p.a $300 \mathrm{mg}$ kemudian diletakkan diatas mortar bersama sampelnya. Campuran sampel dan $\mathrm{KBr}$ tersebut digerus hingga homogen selanjutnya dituangkan ke dalam $\mathrm{KBr}$ Die. Dilakukan pressure $10 \times 1.000 \mathrm{~kg}$ atau setara dengan 10 ton untuk membuat pellet. Dirunning dengan FTIR. Sampel tersebut dianalisis pada bilangan gelombang dari $400-4500 \mathrm{~cm}^{-1}$.

\section{HASIL DAN PEMBAHASAN}

\section{Delignifikasi Serbuk Kulit Durian}

Pada proses delignifikasi ini digunakan bahan baku yaitu serbuk kulit durian yang berukuran 60 mesh. Ukuran partikel sangat berpengaruh terhadap proses mendapatkan senyawa selululosa karena semakin kecil ukuran partikel maka semakin banyak yang terekstrak sehingga jumlah lignin dan hemiselulosa yang terbebaskan semakin meningkat pula.

Hasil proses dari delignifikasi serbuk kulit durian ini diperoleh senyawa selulosa dengan rendemen sebesar 36,573\% berwarna putih. Penelitian yang dilakukan oleh Nur'ain (2016) dengan bahan yang berbeda yakni batang jagung sebesar $36,127 \%$.

Kurniawan (2010) melaporkan bahwa kulit durian secara proposional 
mengandung unsur selulosa yang cukup tinggi yaitu $50-60 \%$, lignin $5 \%$, dan pati $5 \%$. Proses penghilangan komponenkomponen pengotor pada serbuk kulit durian untuk mendapatkan selulosanya dilakukan dengan menambahkan larutan basa yaitu $\mathrm{NaOH} 10 \%$ dan dilakukan perendaman selama 24 jam. Menurut Robinson (1995), penghilangan lignin dengan $\mathrm{NaOH}$ akan ditandai berupa warna merah kehitaman pada larutan. Selanjutnya dilakukan perendaman dengan larutan hidrogen peroksida $10 \%$ untuk mendapatkan selulosa yang berwarna putih serta untuk menghilangkan senyawa lignin dan hemiselulosa yang masih tersisa. Menurut Riama (2012), Hidrogen peroksida dapat melepaskan oksigen dengan cukup kuat. Penggunaan hidrogen peroksida sebagai agen pemucat (bleaching), yaitu tidak menghasilkan residua tau endapan. Larutan hidrogen peroksida tidak mengakibatkan kerusakan berarti pada bahan organik dan dapat menghasilkan produk yang lebih putih dan juga bersih.

\section{Rasio Natrium Monokloroasetat dan Selulosa Terbaik}

Rendemen karboksimetil selulosa (CMC) yang dihasilkan pada berbagai rasio natrium monokloroasetat : selulosa disajikan pada Gambar 1. Jika dilihat dari gambar grafik tersebut rendemen tertinggi karboksimetil selulosa terdapat pada rasio natrium monokloroasetat : selulosa 5:5 gram yaitu sebesar $45,56 \%$.

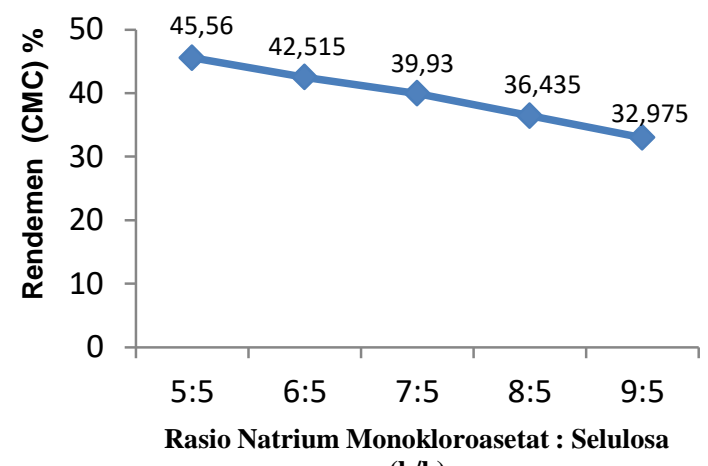

(b/b)
Gambar 1. Pengaruh jumlah natrium monokloroasetat terhadap rendemen karboksimetil selulosa dari kulit durian.

Rendemen yang diperleh pada penelitian ini lebih kecil jika dibandingkan dengan penelitian sebelumnya yang dilakukan oleh Bidin (2010), dengan bahan pembutan karboksimetil selulosa berasal dari selulosa jerami padi diperoleh rendemen tertinngi pada penambahn 6 gram natrium monokloroasetat yaitu sebesar $67,52 \%$ dan penelitian dari Melisa (2014), dengan bahan pembuatan karboksimetil selulosa berasal dari tongkol jagung manis diperoleh rendemen tertinggi pada penambahan 7 gram natrium monokloroasetat yaitu sebesar 69,73\%.

Selain melihat rendemen yang dihasilkan parameter yang penting dalam penentuan kualitas karboksimetil selulosa yang dihasilkan yaitu derajat subsitusi. Derajat subsitusi karboksimetil selulosa yang dihasilkan pada berbagai rasio natrium monokloroasetat terhadap selulosa disajikan pada Gambar 2. Hasil terbaik pada pembuatan karboksimetil selulosa ini yaitu pada rasio natrium monokloroasetat : selulosa 7:5 gram dengan rendemen yang didapatkan 
sebesar 39,93 \% dengan nilai derajat subsitusi sebesar 1,17.

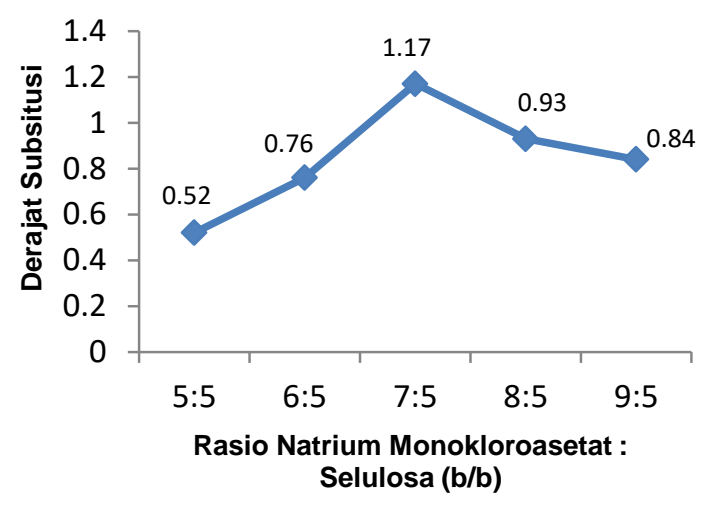

Gambar 2. Pengaruh jumlah natrium monokloroasetat terhadap derajat subsitusi karboksimetil selulosa dari kulit durian.

Jika dibandingkan dengan penelitian sebelumnya yang dilakukan oleh Nur'ain (2016), dengan bahan pembutan karboksimetil selulosa berasal dari selulosa tongkol jagung derajat subsitusi tertinggi yaitu sebesar 0,839 . Menurut Aambjornsson et al., (2013), derajat subsitusi maksimum untuk CMC adalah 3 dengan rata-rata nilai diantara 0,4-1,5. Semakin tingginya nilai derajat subsitusi dari CMC, maka kelarutannya dalam air akan meningkat pula. Derajat subsitusi yang dihasilkan pada penelitian ini berkisar antara 0,52- 1,17.

Proses pembutan karboksimetil selulosa terdiri atas dua tahap yaitu alkalisasi dan karboksimetilasi. Proses alkalisasi pada penelitian ini menggunakan larutan $\mathrm{NaOH}$ 30\%. Penambahan $\mathrm{NaOH}$ $30 \%$ dilakukan secara perlahan selama 1 jam. Hal ini dilakukan agar campuran reaksi merata maka selulosa harus terbasahi seluruhnya oleh larutan $\mathrm{NaOH}$. Fungsi dari $\mathrm{NaOH}$ ini yaitu mengaktifkan gugus-gugus $\mathrm{OH}$ pada molekul selulosa dan sebagai pengembang. Proses pengembangan selulosa ini akan mempengaruhi proses selanjutnya yaitu proses karboksimetilasi dimana kondisi karboksimetilasi akan optimum jika pengembangannya optimum.

Proses karboksimetilasi ini menggunakan Natrium monnokloroasetat. Menurut Wijayani dkk (2005), jumlah natrium monokloroasetat yang digunakan akan berpengaruh terhadap subsitusi dari unit anhidroglukosa pada selulosa. Semakin tinggi reaksi subsitusi maka semakin tinggi pula kualitas karboksimetil selulosa yang dihasilkan.

Dalam proses karboksimetilasi pada penambahan 5-7 gram natrium monokloroasetat terlihat nilai derajat subsitusi semakin tinggi. Hal ini dikarenakan semakin banyak natrium monokloroasetat maka semakin banyak gugus anhidroglukosa yang tersubsitusi.

Sedangkan pada penambahn 8-9 gram natrium monokloroasetat terjadi penurunan derajat subsitusi. Hal ini dikarenakan semakin banyaknya produk samping yang terbentuk sehingga karboksimetil selulosa yang dihasilkan mengalami penurunan nilai derajat subsitusi. Menurut Wijayani dkk (2005), kemurnian dari CMC akan mengalami penurunan jika jumlah natrium monokloroasetat semakin naik. Hal tersebut diakibatkan oleh semakin banyaknya terbentuk natrium klorida $(\mathrm{NaCl})$ dan natrium glikolat 
$\left(\mathrm{HOCH}_{2} \mathrm{COONa}\right)$ yang mengakibatkan turunnya derajat subsitusi.

\section{Waktu Reaksi Sintesis Karboksimetil Selulosa (CMC) Optimum}

Rendemen karboksimetil selulosa yang dihasilkan pada berbagai waktu reaksi disajikan pada Gambar 3.

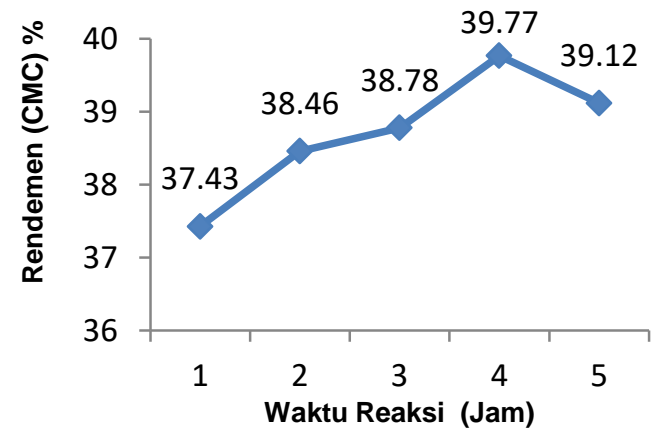

Gambar 3. Pengaruh waktu reaksi terhadap derajat subsitusi karboksimetil selulosa dari kulit durian

Jika dilihat dari gambar grafik tersebut maka dapat dilihat rendemen tertinggi tertinggi terdapat pada waktu reaksi selama 4 jam yaitu sebesar $39,77 \%$. Jika dibandingkan dengan penelitian sebelumnya yang dilakukan oleh Nur'ain (2016), dengan bahan pembutan karboksimetil selulosa berasal dari selulosa tongkol jagung diperoleh rendemen tertinngi pada penambahn 6 gram natrium monokloroasetat yaitu sebesar $91,95 \%$.

Pada waktu reaksi 1 sampai 4 jam rendemen yang dihasilkan semakin banyak dan pada 5 jam waktu reaksi rendemen yang dihasilkan menurun. Hal ini dikarenakan rendemen yang dihasilkan berbanding lurus dengan derajat subsitusi. Semakin banyak gugus $\mathrm{OH}$ pada selulosa alkali yang digantikan oleh gugus karboksimetil dari natrium monokloroastat semakin banyak CMC yang terbentuk sehingga rendemen yang dihasilkan juga tinggi. Derajat subsitusi karboksimetil selulosa yang dihasilkan pada berbagai waktu reaksi disajikan pada Gambar 4.

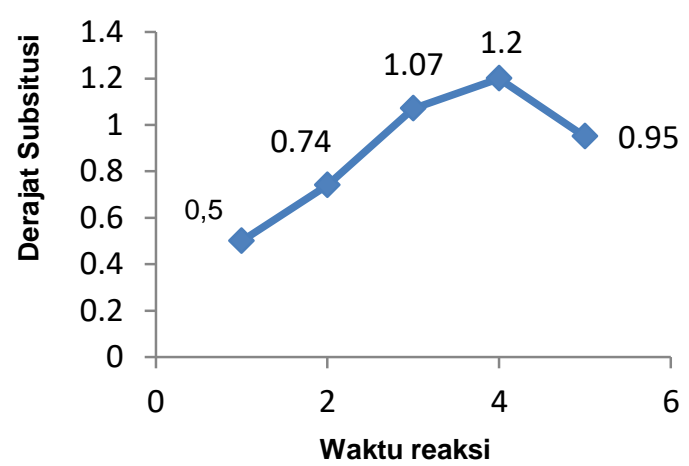

Gambar 4. Pengaruh waktu reaksi terhadap derajat subsitusi karboksimetil selulosa dari kulit durian

Hasil terbaik pada pembuatan karboksimetil selulosa ini yaitu pada waktu reaksi selama 4 jam dengan rendemen yang didapatkan sebesar 39,77 \% dengan nilai derajat subsitusi sebesar 1,2 serta $\mathrm{pH}$ 6,89 . Karboksimetil seulosa yang berasal dari kulit durian ini memenuhi persyaratan CMC mutu I dari SNI. Menurut SNI mutu 1, nilai derajat subsitusi karboksimetil selulosa yaitu 0,7-1,2 serta $\mathrm{pH}$ 6-8. Serta jika dibandingkan dengan penelitian sebelumnya hasil yang diperoleh jauh lebih baik. Menurut penelitian yang dilakukan oleh Nur'ain (2016), dengan bahan pembutan karboksimetil selulosa berasal dari selulosa batang jagung diperoleh rendemen tertinngi pada waktu reaksi selama 4 jam dengan rendemen yaitu sebesar 91,95 \% dan derajat subsitusi tertinggi yaitu 0,785 . 
Jika dilihat dari grafik Gambar 4 pada waktu reaksi 1 sampai 4 jam terjadi kenaikan nilai derajat subsitusi. Peningkatan ini terjadi karena dengan bertambahnya waktu reaksi yang digunakan dalam proses karboksimetilasi akan meningkatkan kesempatan terjadinyaa reaksi subsitusi yang terjadi. Pada waktu reaksi tersebut reaksi berlangsung secara efektif sehingga kontak yang lebih baik antara agen eterifikasi dengan selulosa dan molekul korboksimetil selulosa terbentuk secara sempurna (Pushpamalar dkk, 2005). Pada waktu reaksi 5 jam terjadi penurunan derajat subsitusi. Menurut Pushpamalar dkk (2005), penurunan derajat subsitusi disebakan oleh proses degradasi polimer atau pemecah molekul-molekul besar menjadi molekul-molekul yang lebih sederhana pada karboksimetil selulosa.

\section{Hasil Penetuan Berat Molekul}

Berat molekul karboksimetil selulosa (CMC) yang diperoleh pada waktu reaksi optimum dengan derajat subsitusi tertinggi sebesar $8.174,353 \mathrm{~g} / \mathrm{mol}$. Nilai berat molekul yang didapatkan jauh lebih kecil dari berat molekul yang disyaratkan yaitu 90000. USP (United States Pharmacopeia) mendeskripsikan sodium karboksimetil selulosa merupakan garam sodium yang berasal dari sebuah polikarboksimetil eter selulosa. Berat molekulnya adalah 90000700000. Menurut penelitan yang dilakukan oleh Awaludin dkk (2004), karboksimetil selulosa (CMC) yang diperoleh dari selulosa bakteri memiliki berat molekul $48.885 \mathrm{~g} / \mathrm{mol}$, sedangkan karboksimetil selulosa (CMC) dari selulosa tumbuhan memiliki berat molekul $34.235 \mathrm{~g} / \mathrm{mol}$.

\section{Spektrum FTIR Karboksimetil Selulosa (CMC) dari Kulit Durian}

Spektrum FTIR karboksimetil selulosa yang dihasilkan pada rasio natrium monokloroasetat : selulosa terbaik dan waktu reaksi optimum disajikan pada Gambar 5 .

Pada gambar diatas dapat dilihat spektra FTIR karboksimetil selulosa dari kulit durian. Munculnya bilangan gelombang 3417 adalah gugus $\mathrm{OH}$ yang merupakan ciri khas dari selulosa. Menurut Eriningsih (2011), gugus fungsi $\mathrm{OH}$ sangat kuat pada bilangan gelombang $3427 \mathrm{~cm}^{-1}$. Menurut Saputra dkk (2014), pada panjang gelombang $3700-3100 \mathrm{~cm}^{-1}$ merupakan gugus $\mathrm{OH}$ yang menunjukan terbetuknya kelompok ikatan hidrogen antara atom hidrogen dalam satu kelompok gugus hidroksil lain monomer glukosa pada rantai polimer selulosa.

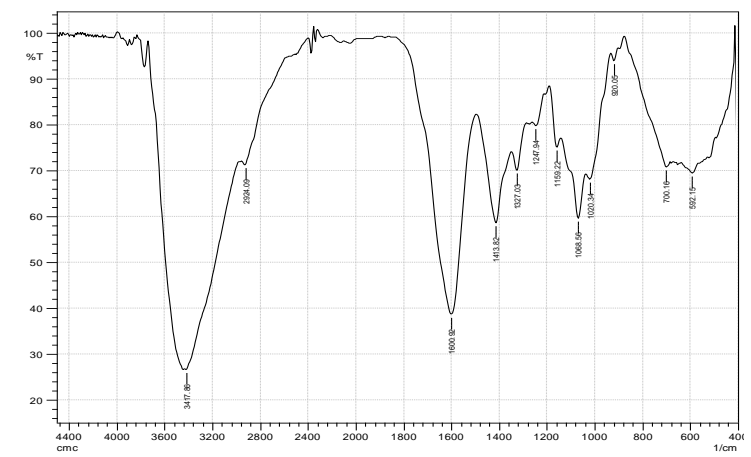

Gambar 5. Spektrum FTIR Karboksimetil selulosa

Munculnya vibrasi pada bilangan gelombang 2924 merupakan gugus $\mathrm{C}-\mathrm{H}$. 
Menurut Eriningsih (2011) gugus hidrokarbon $(\mathrm{C}-\mathrm{H})$ pada bilangan gelombang sekitar $2950 \mathrm{~cm}^{-1}$. Pada bilangan gelombang 1413 menujukan adanya gugus $-\mathrm{CH}_{2}$. serta pada panjang gelombang 1600 menujukan adanya gugus karboksil. Menurut Lestari dkk (2014), CMC teridentifikasi mempunyai gugus karboksil pada panjang gelombang $1604 \mathrm{~cm}-1$ dan ikatan $-\mathrm{CH}_{2}$ pada panjang gelombang $1419 \mathrm{~cm}^{-1}$. Berdasarkan identifikasi tersebut terbukti bahwa CMC yang dihasilkan mempunyai kemiripan gugus fungsi dengan CMC komersial dan mempunyai bilangan gelombang yang menunjukkan gugus konstituen pada CMC yaitu gugus karboksil dan $-\mathrm{CH}_{2}$.

Pada bilangan gelombang 1068 menunjukan adanya eter yang terbentuk yaitu gugus $\mathrm{C}-\mathrm{O}-\mathrm{C}$. Menurut Eriningsih (2011), gugus eter (-O-) pada 1049 cm-1. Dari hasil gugus fungsional yang terukur dari spektrum FTIR dengan dengan masing-masing serapan pada daerah panjang gelombang tertentu menunjukan kesesuaian dengan struktur karboksimetil selulosa. Hal ini ditandai dengan terdapatnya vibrasi $\mathrm{OH}$, ikatan - $\mathrm{C}-\mathrm{H}$, gugus karboksil (COO-), ikatan $-\mathrm{CH}_{2}$, dan gugus eter (-O-).

\section{KESIMPULAN}

Berdasarkan hasil penelitian yang telah dilakukan, didapatkan rasio terbaik natrium monokloroasetat : selulosa yang menghasilkan karboksimetil selulosa dari kulit durian yaitu $7: 5$ dengan nilai derajat subsitusi sebesar 1,17 dan waktu reaksi optimum yang menghasilkan karboksimetil selulosa dari kulit durian yaitu 4 jam dengan nilai derajat subsitusi sebesar 1,2 .

\section{UCAPAN TERIMAKASIH}

Secara khusus peneliti menyampaikan ucapan terima kasih kepada Laboran Jurusan Kimia FMIPA UNTAD.

\section{DAFTAR PUSTAKA}

Aambjornsson HA., K. Schenzel., U. Germgard. 2013. Carboxymethyl cellulose Produced at Different Mercerization Condition and Caracterized by NIRFT Raman Spectroscopy in Combination with Multivariate Analytical Methods, BioResources. 8(2):1918-1932.

Awaludin, A, 2004. Karboksimetilasi Selulosa Bakteri, Fakultas matematika dan ilmu pengetahuan alam. [Skripsi]. Bogor: IPB.

Bidin A. 2010. Optimasi Kondisi Reaksi Sintesis Karboksimetil Selulosa dari Jerami Padi (Oryza sativa), [Skripsi]. Palu: Program Studi Kimia Universitas Tadulako.

Dumanauw, J.F, 1990, Mengenal Kayu, Yogyakarta: Kanisius.

Eriningsih R., Rizka Yulina, Theresia Mutia. 2011. Pembuatan Karboksimetil Selulosa Dari Limbah Tongkol Jagung Untuk Pengental Pada Proses Pencapan Tekstil, Jurnal IImiah Arena Tekstil. 26 (2): 105-113.

Habibah R., Nasution DY., Muis Y. 2013. Penentuan Berat Molekul Dan Derajat Polimerisasi A - Selulosa Yang Berasal Dari Alang-Alang (Imperata Cylindrica) Dengan Metode Viskositas, Jurnal Saintia Kimia. 1(2).

Kurniawan D. W., Arifan, F., Adim, M. D. K. 2013. Pembuatan Pulp dengan Memanfaatkan Limbah Kulit Durian 
(Durio zibethinus Murr) dengan Campuran (Resina colophonium) Guna Mencegah Degradasi Lingkungan, Jurnal Gema Teknologi. 17 (3): 100-102.

Lestari P., Titi Nur H., Siti Hanum I. L., Djagal Wiseso M. 2014. Pengembangan Teknologi Pembuatan Biopolimer Bernilai Ekonomi Tinggi Dari Limbah Tanaman Jagung (Zea mays) Untuk Industri Makanan: CMC (Carboxymethylcellulose). [Skripsi]. Yogyakarta: Universitas Gadjah Mada.

Melisa. 2014. Optimasi Sintesis Karboksimetil Selulosa Dari Tongkol Jagung (Zea mays $L$ Saccharata), Jurnal of natural science. 3 (2) : 70-78.

Nur'ain, 2016, Optimasi Kondisi Reaksi Untuk Sintesis Karboksimetil Selulosa (CMC) Dari Batang Jagung (Zea mays L.). [Skripsi]. Palu: Universitas Tadulako.

Pribadi T. 1985. Pembuatan CMC dan Pemurnian Sodium Karboksimetil Selulosa (CMC), Berita Selulosa, XXI. (4): 135-140.

Pushpamalar V. Langford, S.J., Ahmad, M., Lim Y.Y. 2006, Optimization of rection condition for preparing carboxymethyl cellulose from sago waste, Carbohydrate Polymers 64: 312-318.

Riama G. 2012. Pengaruh $\mathrm{H}_{2} \mathrm{O}_{2}$, Konsentrasi Naoh Dan Waktu Terhadap Derajat Putih Pulp dari Mahkota Nanas, Jurnal Teknik kimia, 18 (3) : 25-34.

Robinson T.E. 1995. Kandungan Organik Tumbuhan Tinggi. Bandung: ITB.

Saputra A.H.; Qadhayna, L.; Pitaloka, A.B. 2014. Synthesis and Characterization of Carboxymethyl Cellulose (CMC) from Water Hyacinth Using Ethanol-Isobutyl Alcohol Mixture as the Solvents, International Journal of Chemical Engineering and Applications. 5(1): 36-40.
Wijayani, A., U. Khoirulah dan T. Siti, 2005, Karakterisasi Karboksimetil Selulosa (CMC) dari Eceng Gondok (Eichornia crassipes (Mart) Solms). Indo. J. Chem. 5 (3): 228 - 23. 